\title{
Infrastructural Violence: Five Axes of Inequities in Water Supply in Delhi, India
}

\author{
Ashok Kumar $^{1 *}$, Nitin Singh ${ }^{1}$, Sarah Cooper ${ }^{2}$, Anna Mdee $^{2}$ and Shivani Singhal ${ }^{2}$ \\ ${ }^{1}$ Department of Physical Planning, School of Planning and Architecture, New Delhi, India, ${ }^{2}$ Department of Social Science, \\ School of Politics and International Studies, University of Leeds, Leeds, United Kingdom
}

Inequity is deeply embedded in the supply of drinking water in Delhi, India. Using the concept of infrastructural violence, this paper exposes how past and present governance of water has resulted in unequal distribution of supply across the city to exclude vulnerable communities from accessing drinking water. This perspective broadens the gaze away from a narrow gaze on the technical and structural aspects of infrastructure to encompass the socio-political dimensions. This paper starts by outlining the history of the water supply in Delhi. We then outline five axes of exclusion which can be read as infrastructural violence and explores how aspects of water policy, legislation, and planning uphold these injustices. Our discussion centers on how economics, political ideology, and power infiltrate governing mechanisms to influence water infrastructure to entrench poverty and marginalization. Attempts to improve water security for Delhi's

OPEN ACCESS

Edited by:

Miguel R. Peña,

University of Valle, Colombia

Reviewed by:

Jamie Linton

University of Limoges, France

Maurizio Mazzoleni,

Uppsala University, Sweden

*Correspondence:

Ashok Kumar

a.kumar@spa.ac.in

Specialty section:

This article was submitted to Water and Human Systems,

a section of the journal

Frontiers in Water

Received: 18 June 2021 Accepted: 07 October 2021 Published: 10 November 2021

Citation:

Kumar A, Singh N, Cooper S, Mdee A and Singhal $S$ (2021) Infrastructural Violence: Five Axes of Inequities in

Water Supply in Delhi, India.

Front. Water 3:727368.

doi: 10.3389/frwa.2021.727368 residents face minimal impact without addressing these embedded inequities. Therefore, our analysis offers a framework to systematically create awareness of the factors to be addressed to enable a more equitable governance of water supply.

Keywords: infrastructural violence, active infrastructural violence, passive infrastructural violence, water inequities, five axes of exclusions

\section{INTRODUCTION}

The city of Delhi in India has undergone extensive transformations over the recent decades. The roots of this change are embedded in the drive for liberalization since the early 1990s, which stimulated infrastructural planning to establish Delhi as a global city and as a world leader on the international stage (Dupont, 2011; Ghertner, 2015; Baviskar, 2020). Actions to achieve this status are epitomized by the hosting of the Commonwealth Games in 2010, where the authorities used this event as a "catalyst for urban change" and an opportunity to showcase global ambitions of making the city "world class." Throughout this period and, particularly in a more recent on-going restructuring of the urban landscape, analysis suggests that the socio-economic realities which underpin this drive for urban change, and the nefarious routes taken to achieve this vision has resulted in the marginalization and displacement of the urban poor (Dupont, 2008; Bhan and Shivanand, 2013; Bhan, 2016).

India implemented Liberalization, Privatization, and Globalization (LPG) reforms in 1991 which opened up various sectors, including water utilities, for global private companies. As a consequence, the state passed responsibility for the delivery of basic water and sanitation services to private companies whose primary aim was to maximize their profits. This new water discourse was further bolstered by the Ministry of Water Resources (2002) encouraged public-private partnerships in "planning, development, and management of water projects for diverse uses, wherever feasible" 
(Ministry of Water Resources, Government of India, 2012). A secret attempt was made to privatize the Delhi Jal Board (DJB), the state institution delegated with the responsibility of water supply and sanitation provisioning, just its establishment in 1998. During the same period, Sonia Vihar Water Treatment Plant whose construction, operation and management were awarded by the DJB to global water giant Ondeo Degremont exacerbated water inequity in parts of the city as initially it was decided that Delhi's new supply from Sonia Vihar will go to the richer South Delhi areas, and not to poor neighborhoods (Shiva, 2006). Water from Sonia Vihar WTP is supplied round the clock, and is meant for residents of DJB's South zones II and III, which comprises more advantaged residents.

This period witnessed the development agenda shift from welfare-oriented policy regimes to market-led policies; cities transforming themselves, rhetorically at least, to hubs of economic creation, urbanization, and industrialization. Due to the negligible return from agricultural activities and the negative connotations of them being viewed as "backward" occupations (Bentinck, 2000, p. 100); there has been a structural economic transformation, with people moving from agriculture to the service sector. Moreover, increasing wealth and income inequality have shifted the social narrative of poverty (Fernandes, 2006). Now slum dwellers are not suffering from poverty but are deemed a nuisance. They do not fit in with global aspirations, their lived reality, if not erased, is hidden. This was evidenced by the "Pushta settlement evictions" before the 2010 Commonwealth Games, when slum dwellers were hidden from view by bamboo screens (Baviskar, 2019). Intolerance to poverty is now within the moral and ethical compass. Moreover, justifications for evictions of the poor used by the state, police and press, frames the evicted as foreigners. During the Pushta demolition, residents were repeatedly referred to as Bangladeshi and Pakistani (Adve, 2004).

There is a frustration seen among the middle class against the welfare programs provided to the weaker sections of the society (Chaplin, 2011, p. 66). This change has made it possible to villainizing slum dwellers and paved the path for their evictions and relocation. This can be seen in the narrative of the state, the judiciary, the media, and the middleclass population leading up to the Commonwealth Games (Ghertner, 2015). Many infrastructure policies were launched by the government in the wake of the Commonwealth Games. These were supported by moralizing, modernizing, and cleanup policies (Baviskar, 2019, p. 89). If the urban poor came in the way of implementation of these policies, they were to be set aside. The building of the Delhi Metro (underground and overground public transport) and Akshardham Temple are recent notable examples. Redevelopment of slum lands is another illustration of restructuring and modernizing the city. This type of transformative development of the city displaces the poor and embeds inequality (Kumar, 2020; also see Kumar et al., 2021).

Evidence suggests that displacements and evictions of low-income families are the visible spatial manifestations of inequitable urbanization in India. Over-riding reasons for displacements and evictions in Indian cities are clashes and conflicts between the needs of the urban poor and the aspirational classes (Baviskar, 2019). Moreover, while the middle class meets its demand through unauthorized colonies, which in time are legitimized and recognized by the government, whereas the unauthorized residents of slums are more likely to be evicted. Roy (2011, p. 259) refers to this as the "expansion of the urban frontier, a making way and making space for the new Indian middle class, through the smashing of the homes and livelihoods of the urban poor," a theme also explored by Watson (2009) and Bentinck (2000).

This paper proposes that the concept of infrastructural violence allows us to make sense of the processes which drive and underpin inequalities in water access in Delhi.

Infrastructural violence questions the perceived material and technical innocuousness of infrastructure, whilst highlighting infrastructure's ability to create and shape deep inequalities within urban environments. We then turn our focus onto the domestic water supply in Delhi and outline how the city's colonial legacy has shaped infrastructural inequality and exclusion in contemporary Delhi. Within this context we identify five axes of inequality and exclusion which drive infrastructural inequality and then finally, we consider how these axes shape water infrastructural violence in Delhi and set out the challenges that need to be addressed to enable a more just and equitable future.

\section{INFRASTRUCTURAL VIOLENCE IN THE "WORLD CLASS CITY"}

Official disregard for the urban poor is fundamentally illustrated by inequitable access to basic services and the planning, governance, and decision-making processes that sit behind infrastructure provision. These decision-making processes are embedded across multiple layers of governments, agencies, and actors in a way that impedes accountability to the public and obscures the responsibility of the state. Rodgers and O'Neill (2012) refer to this phenomenon as "infrastructural violence" derived from the concepts of "infrastructural power" by Mann (1984) emphasizing institutional regulation of society by elites. Infrastructural violence also links up with "infrastructural warfare” coined by Graham (2004, 2006, 2010) producing infrastructure provision that induces human suffering (Rodgers and O'Neill, 2012, p. 403).

The concept of infrastructural violence shifts our perceptions from the conventional understanding of infrastructure as material and technical urban systems to infrastructure as sociotechnical regimes. So, infrastructural violence occurs when residents are either excluded from essential infrastructures such as water or sanitation services by acts of displacement or inadequate infrastructure provisioning. Both denial and exclusion cause human suffering. Infrastructural violence also takes place through "articulations of infrastructure that are designed to be violent” (Rodgers and O'Neill, 2012, p. 402). Renu Desai explains that infrastructure is designed to be violent by "the ways in which urban planning, policies and governance forge infrastructure that produces ... inadequacies and everyday deprivations, burdens, inequities, tensions and conflicts in residents' lives" (Desai, 2018, p. 89). 
Rodgers and O'Neill (2012) identify two types of infrastructural violence: active and passive. When infrastructure is intentionally designed to be violent, it is active, for instance, the building of elite infrastructure such as a promenade for sportspersons during the 2010 Commonwealth Games in Delhi after the demolition of slums. Passive infrastructural violence refers to the "socially harmful effects derived from infrastructure's limitations and omissions." For example, people are being excluded from infrastructure networks. Truelove and O'Reilly (2020, p. 5) further highlight the role of infrastructure as a force that shapes social experiences and subjectivities, bringing into focus the distinct position it has in mediating relations between humans and their environment through the maintenance of, for example, regulatory standards, corporate interests, social expectations, and historical legacies of organization and supply (Amin, 2014, p. 138).

Viewing infrastructure provision in this way highlights the agency, power relations, and ideologies which sit behind decision making and resourcing. In addition it draws attention to uneven rights, application of regulations and distribution of infrastructure; not only in the present but also as legacies from the past where historical decisions collide with future aspirations to produce and reproduce inequalities (Rodgers and O'Neill, 2012; Truelove and O'Reilly, 2020). Inequalities are further entrenched through the socio-spatial decisions of infrastructure providers, the rules of supply and tariffs, and the gulf of access between geographical areas and demographic groups. Truelove and O'Reilly (2020) probe further into these structural injustices through the theme "infrastructural intersectionality" which explores how the intersections of social identities such as gender, class, caste, and power relations are further preserved or exacerbated through infrastructures. This is illustrated in Delhi by the development of the Delhi Metro, Akshardham Temple, and the Commonwealth Games, where the intersectionality of power, caste, religion, and class saw the clearing of poor settlements and slums to make way for the aesthetics and needs of the middle class. On similar lines, Sims' (2021) fieldwork in Laos shows that large infrastructure projects frequently manifest in infrastructural violence for more disadvantaged populations.

Infrastructural violence in Delhi is by no means isolated to these large, impactful showcase developments but also extends to other (essential) infrastructural systems. In this paper, we explore the extent to which this form of violence is inherent within the supply of drinking water. Access to drinking water in Delhi is deeply inequitable across all of its approximately 20 million inhabitants. An estimated half of these residents are not connected to the centralized water network and have to rely on other means such as tankers, private taps, tube wells, and standpoints. Shortages of water are common in many areas of the city. Many who are connected generally have water only for $2-4 \mathrm{~h}$ a day, whereas some neighborhoods have 24 -h access (Truelove, 2019).

So, why do these inequities exist and why do they persist? This is the question that underpins this paper. Here, we seek to understand the actions and decisions which produce discriminatory governance of the drinking water supply for the urban poor. Through a historical and structured analysis, we aim to make a contribution to the theme of infrastructural violence by providing examples of how the relationships of hierarchy and power manifest to create inequitable access.

We initially outline the context of demographic marginalization in Delhi and how this relates to the water supply. We then briefly turn to the history of water supply to marginalized communities in Delhi to provide context as to how inequity in the present-day system has become embedded. This then frames five axes of exclusion relating to aspects of water policy, legislation, and planning which continue to reproduce water injustices. Our discussion centers on how economics, political ideology, and power infiltrate governing mechanisms to influence water infrastructure to entrench inequitable access to services through forms of infrastructural violence.

\section{WATER ACCESS AND MARGINALIZATION IN DELHI}

Many of Delhi's residents live in slums or unauthorized residential developments with high levels of deprivation, with sub-standard accommodation and residents struggling to access basic amenities like water and sanitation. The development of Delhi as a world-class city has resulted in a mass influx of poor migrants seeking employment whilst their cheap labor sustained the "modernization" of the city (Biswas, 2020). It is estimated that there are 450 million informal sector workers in India, nearly $90 \%$ of the entire workforce. The total number of workers in Delhi was 5,587,000 as per the Census of India 2011 (Government of the National Capital Territory of Delhi, 2019, p. 89). Based on the assumption that $90 \%$ of the working population is engaged in the informal sector, the number of informal sector workers might be in the region of 5,028,300. Informal workers are vulnerable, characterized by low wages. They often lack medical insurance (Bora, 2014), access to adequate housing and infrastructure, and have limited collective bargaining capacity (Baviskar, 2019).

Current urban policies have perpetuated displacements and evictions, and consequently continued to push the poor toward the physical and societal periphery. Evictions of slums and squatters from the city to its margins could be treated as the domination of urban space by the elite; when evicted spaces are rendered out of reach of the urban poor, owing to new land uses such as malls and entertainment plazas. Geographical distance from employment opportunities marginalizes the poor by making access to these places potentially expensive for travel. Long shifts make it impossible for the workers to travel from the outskirts of the city to work. Moreover, there are no formal residential areas planned for these workers near construction sites and factories. As a result, they have little option other than to build homes near their work areas. Here, exploitation in the form of loss of livelihoods and domination in the form of evictions from the city to the margins are not only socially and spatially manifested, but also socially and spatially produced and reproduced (Speak, 2012).

Most of these informal urban dwellers live in 6-10 $\mathrm{m}^{2}$ huts in slums, where water is accessed through public taps, tankers, and tube wells. According to the Comptroller and Auditor General 
TABLE 1 | Daily water supplied and population served through tankers in the DJB's administrative divisions.

\begin{tabular}{|c|c|c|c|c|c|c|c|c|c|c|}
\hline \multirow[t]{2}{*}{ S. No. } & \multirow[t]{2}{*}{ Division } & \multicolumn{3}{|c|}{ Quantum of water supplied in Million Gallons (MG) } & \multicolumn{3}{|c|}{ Population ('000) } & \multicolumn{3}{|c|}{ Per capita water availability per day in liters (L) } \\
\hline & & 2009-10 & $2010-11$ & 2011-12 & 2009-10 & $2010-11$ & 2011-12 & 2009-10 & $2010-11$ & 2011-12 \\
\hline 1. & Central II & 10.64 & 15.54 & 21.51 & 45 & 45 & 45 & 2.94 & 4.3 & 5.95 \\
\hline 2. & North West I & 131.4 & 131.4 & 146 & 425 & 450 & 475 & 3.85 & 3.63 & 3.82 \\
\hline 3. & North West II & 200.29 & 165.27 & 171.72 & 99.65 & 82.23 & 85.44 & 25 & 25 & 25 \\
\hline 4. & North West III & 5.07 & 5.27 & 5.71 & 50 & 50 & 50 & 1.26 & 1.31 & 1.42 \\
\hline 5. & North East I & 51.82 & 48.97 & 48.15 & 98 & 95 & 90 & 6.58 & 6.41 & 6.65 \\
\hline 6. & North East II & 49.52 & 51.41 & 53.56 & 56 & 60 & 62 & 11 & 10.66 & 10.75 \\
\hline 7. & North East III & 14.85 & 13.55 & 12.22 & 100 & 100 & 100 & 1.85 & 1.69 & 1.52 \\
\hline 8. & East I & 15.41 & 15.45 & 15.41 & 66 & 66 & 66 & 2.9 & 2.91 & 2.9 \\
\hline 9. & East II & 10.78 & 9.8 & 10.08 & 52.4 & 52.4 & 52.4 & 2.56 & 2.33 & 2.39 \\
\hline 10. & South I & 70.44 & 60.19 & 80.79 & 310 & 310 & 310 & 2.83 & 2.42 & 3.24 \\
\hline 11. & South III & 36.84 & 46.74 & 50.36 & 676 & 676 & 676 & 0.68 & 0.86 & 0.93 \\
\hline 12. & South IV & 130 & 130 & 130 & 500 & 500 & 500 & 3.23 & 3.23 & 3.23 \\
\hline 13. & South West I & 90 & 90 & 100 & 270 & 270 & 27 & 4.15 & 4.15 & 46.07 \\
\hline 14. & West III & 106.93 & 106.93 & 106.93 & 215 & 215 & 215 & 6.19 & 6.19 & 6.19 \\
\hline 15. & North & 3.5 & 46 & 48.5 & 400 & 450 & 500 & 0.11 & 1.27 & 1.21 \\
\hline Total & & 927.49 & 936.52 & 1000.94 & 3363.05 & 3421.63 & 3253.84 & 3.42 & 3.4 & 3.82 \\
\hline
\end{tabular}

Source: Comptroller and Auditor General of India (2013).

of India (2013) report, during 2011-12 period 24.8\% of the households in Delhi were not connected to the DJB's water supply network. A majority of these households were part of the unauthorized colonies and Jhuggi Jhopari clusters situated on the periphery of the city. In the absence of formal water supply infrastructure, water was being supplied through water tankers and just 1,000.94 Million Gallon (MG) of water was supplied for the whole year at the rate of 3.82 liters per capita per day (LPCD) against the official norm of 172 LPCD (Comptroller and Auditor General of India, 2013). Table 1 shows the quantum of water supplied to around 3,300,000 people living is various parts of Delhi out of which around 2,553,000 people were living in informal settlements. This large portion of Delhi's population was relying on the provision of water through tankers in absence of access to the centralized piped water supply system.

In extreme peripheral areas, residents are forced to buy expensive bottled water from the private vendors, who buy water from the DJB. Community toilets, if provided by the government, generally do not work because the water for flushing is provided only for few hours. Over a period of time, these community toilets become dysfunctional and people have to resort to open defecation. Census of India 2011 has reported that Delhi's 10\% ( 2 million people) population openly defecates. Results of the 76th NSO survey conducted between July and December 2018 showed that $0.5 \%$ of Delhi's population have no access to toilets and $4.8 \%$ population uses community toilets with payment. Since most community toilets do not work, in Delhi, $5.1 \%$ population $(867,000)$ has no option but to defecate in the open (NSO, 2018, p. 99).

Moreover, after centuries of caste-based discrimination, the lower castes have higher levels of poverty. Even if people have the same economic status, it has been reported that due to exclusion, the lower castes will still have lesser water and sanitation facilities
(Kumar, 2014, p. 129). As a result, caste plays a prominent role in infrastructure fragmentation. Despite the important role these workers played in the development of Delhi, they are not treated as full citizens, with the state viewing these communities as on the margins of economic and social class. This is done by creating an exclusionary citizenship narrative where the upper-middle-class refers to themselves as "lawful citizens of Delhi" (Bhan, 2016). This marks the rest as unlawful and non-citizens, targeting them and stripping them of their rights. A manifestation of this view can be seen when it comes to the city's approach in supplying drinking water (Biswas, 2020). We first examine the colonial roots of present day inequalities.

\section{Colonial Legacy of Infrastructural Exclusion}

Divisions within communities and access to water are not a recent phenomenon and can be traced back to the Mughal times in the sixteenth century. Delhi, the new capital city of the British Empire was built in the first half of the twentieth century. The city was built based on the modernist principles of order and functionality. However, surveillance, discipline, and control of the locals was also a prime motivation (Gooptu, 2001, p. 71). Piped water and sanitation services were provided to all ruling classes living in the white town, the Lutyens Delhi, named after Edwin Lutyens, designer and planner of the city.

In contrast, from the twelveth to nineteenth century, residents of Old Delhi predominantly relied on Baoli (a tank with steps on four sides leading down to the water), neighborhood wells, individual household wells, canals, and rivers. There were 607 wells in Delhi during the Mughal times. Due to the decentralized system, locals had various ways of accessing water such as by using the Persian wheel, a mechanical device used for lifting water where the wheel is pulled by animals like bullocks, buffaloes, or 
camels. Water was distributed locally in leather bags (Hardiman, 2002, p. 112). Class differentiation existed during the Mughal times. Poor residents took water from rivers and canals while the rich had dug wells in their houses and neighborhoods (Hosagrahar, 2010, p. 114-116). Thus, the lower castes had to rely on the upper castes. Moreover, this decentralized system was not supported by the kings and could be disrupted by them. For example, Sultan Alauddin Khilji forbade devotees to dig a baoli at Sufi saint Nizamuddin Auliya's shrine (Wescoat, 2014). In this way, the Mughal and the British colonial legacies laid the foundations of inequitable water supply systems in the city over several centuries.

The water supply system was mostly decentralized in the preBritish era. This continued until the revolt of 1857 prior to which the Europeans and the Indians lived in a mixed settlement. However, the post-1857 period residents saw clear segregation of living spaces, and one-third of the city was demolished and rebuilt to "sanitize, improve, and modernize." There was a need felt to "enlighten and civilize" the locals through superior science and technology (Sharan, 2006, p. 4906). These steps were also motivated by the safety of the British residents and the health of the troops. Urban governance measures that were being carried out in Britain since the 1840s were replicated in India. Sanitary concerns of the "Indian" became important to the British after the sanitation recommendations given by the Royal Commission on the Sanitary State of the Indian Army in 1863. The sanitary concerns however were strategic as the new army and governmental zones were provided with water and sanitation facilities and not the older parts of the town (Gooptu, 2001, p. 71).

The decentralized system of wells was classified as un-modern, unimproved, and unsanitary and thus had to be replaced. The state claimed ownership of all natural resources and instituted taxation (Broich, 2007, p. 346). The introduction of piped water in the 1890 s resulted in a gradual but deliberate decay and closure of wells (Gupta, 1981). It can be claimed that this centralization of the water supply was a step closer to controlling and policing the Indians efficiently.

While piped water was resisted in many parts of the British Empire, in India the resistance focused on two major points. Firstly, religious protests against piped water were carried out by the Hindu community as piped water was believed to be impure and could not be used in many religious ceremonies. Additionally, the sealing of wells caused protests motivated by traditional worship practices (Broich, 2007, p. 360). Secondly, newspapers such as "Safir-i-Hind" and "Anjuman-i-Panjab" raised voices against taxation demanded from locals to cover infrastructure costs (Kishore, 2015, p. 457). However, Indians gradually integrated piped water into their daily lives and religious practices.

Along with replacing the wells, the wide network of Mughal drains was replaced with a network of underground drains by the Delhi Municipal Committee to modernize the system. However, the inefficiency of this project can be seen by the statement issued by the Sanitary Commissioner of Punjab in 1873 calling the drains aimless and haphazard. Due to a purported shortage of funds, piped water could not be made available to the Indian part of the city. As a result, it was implemented in a targeted way, prioritizing the white areas and the troops (Kishore, 2015, p. 452). This questions the enlightenment quest claimed by the British officials. Another change in water governance was the application of public nuisance laws. While this law was borrowed from the English judiciary, its Indian application saw extensive use. It covered the destruction of public property that included centralized water systems such as rivers and lakes (Anderson, 2011). As a result, mostly the economically lower sections of the society, which mainly comprised lower castes and enjoyed using water from public sources, were rendered as illegal users.

Therefore, three distinct water supply systems existed during the British colonial period. A "modern" piped water supply network covered New Delhi. This network was meant exclusively for white rulers and Indian bureaucrats who served the Empire. Rich Indians had dug wells within their houses, which formed the second system of water supply. Other Indians, mostly poor classes, procured water from public wells, canals, ponds, etc. Therefore, a majority of the population did not have access to safe drinking water. Limited access to the modern piped water supply is clearly a visible form of active infrastructural violence where infrastructure designed creates a form of violence toward the poor Indian population.

The security and comfort of the colonial population appear to be the underlying motivation in planning separate infrastructure for the British ruling elite and the dominated Indians. However, the situation was also more complex. Religious belief systems agitating against the installation of modern networks of water supply and provisioning of sanitation services combined with caste and class produced a water supply infrastructure that embeds violence to those most disadvantaged within it.

Caste identity played a huge part in preventing access to water to lower castes, particularly the erstwhile untouchables who were prohibited from using water bodies meant for the higher castes. Those who protested against this unjust water practice faced violence. A progressive resolution was passed in 1926 when the government of Bombay Provinces abolished this unjust practice against the untouchables. The Chavdar Lake, the largest reservoir in the Mahad municipality became the focal point for asserting the untouchables' right to water. On 19 March 1927 Babasaheb Bhim Rao Ambedkar led tens of thousands of people gathered at the Chavdar Lake to exert their right to water. Soon after touching the water of the Chavdar Lake, violence followed. The higher castes "spared no one-men, women, or children-knocking our food into the dirt and pounding our utensils" (Jadhav, 2003, p. 39). Since peaceful existence was the pre-requisite for the perpetuation of the colonialist regime, the British supported the higher castes. Consequently, on 4 August 1927, the progressive resolution was revoked by the Mahad municipality. This incident might be short-lived, but it gave rise to a movement to secure water rights for the untouchables.

Overcoming historical legacies of power and privilege is onerous because transcending these legacies requires actions to dismantle the established regimes of which current political parties have become an integral part. So the "civilizing mission" of the colonial regime got easily extended into the Indian republic's polity after 1947 (Fischer-Tine and Mann, 2004). 
Extension of this geographically and temporally uneven and inequitable water regime has been so firmly established that changing this system into a more egalitarian regime appears to be an impossibility in the near future.

\section{Post-colonial Water Supply: The Continuation and Embeddedness of Infrastructural Inequality}

When elite Indians led by the first Prime Minister Jawaharlal Nehru took reins of power from the British colonists in 1947, the modernist policies of city building continued. Nehru looked upon slums with disdain and wanted them demolished. He aspired that all Indians should live in planned areas with access to potable water and sanitation services. Modernist at heart, Nehru wanted to build new towns such as Chandigarh. In Delhi, it was he who brought in the Ford Foundation for the preparation of the Master Plan for Delhi, 1981. Expectedly, the development plan contained policies on slum rehabilitation and resettlement (Delhi Development Authority, 1981). Delhi Master Plan, 1981 paved the way for active and passive infrastructure violence toward slum dwellers and general residents of Delhi. The old city of Shahjahanabad had a gross density of 350 persons per acre with congested built structures, lacking community facilities resulting in poor living conditions. To improve the built environment of the area its population density was proposed to be brought down to 250 persons per acre. As a result, houses were demolished and people were forced to relocate. The same measures were proposed for other areas also to reduce the population density between 200 and 250 persons per acre. On a similar trajectory, quarry laborers working and living in the Anand Parbat area were proposed to relocate in the cheap housing units in the North and South of Delhi. In order to provide housing to slum dwellers by relocation, poor quality housing and infrastructure were built. The poor housing and infrastructure were justified in the name of costcutting and building by-laws, making a classic example of active infrastructural violence toward the resettled (Delhi Development Authority, 1981).

Active infrastructure violence was also seen when Prime Minister, Indira Gandhi followed the principles of modernity during the Emergency between 1975 and 1977 (Hameed, 2017, p. 111). In Delhi, there were large-scale expulsions of people from the center to peripheral locations (Tarlo, 2003). While around 700,000 families were evicted (Baviskar, 2020, p. 152), only 152,300 were resettled (Dupont, 2004, p. 161). Muslim settlements in Old Delhi were especially targeted by $\mathrm{Mr}$ Jagmohan Malhotra, then Vice-Chairman of DDA, also known as the "demolition man" (Hameed, 2017, p. 111). Through these acts of active infrastructural violence, slum dwellers are forced into long-term insecurity. Their fate depended on the leadership of political parties and their agendas.

Drinking water production and distribution became an increasing challenge for the post-colonial regimes in urban India with a fast increasing city population, diminishing water resources, inadequate financial resources to build water and sanitation networks, and deteriorating quality of groundwater. An old and inequitable system of water planning was easily adopted in spite of loud political rhetoric of equal and universal access.

Delhi has a long history of networked water supply. Delhi Joint Water and Sewage Board (DJW\& SB) was set up in 1926 by the British colonists and was responsible for the operation and maintenance of waterworks in Delhi. However, its primary beneficiaries were areas with colonial settlements. This included the area of the Delhi Municipal Committee where a large majority of ruling classes lived (Delhi Administration, 1976, p. 725).

The two most important governing arrangements that exist today are DJB and the Delhi Development Authority (DDA). These play a vital role in both the active and passive infrastructural violence related to the water supply in Delhi. We will explore this further below through a discussion of five axes of infrastructural exclusion. Within 6 years of the formation of the Delhi state, the DJB was created in 1998 by an act of the Government of the National Capital Territory of Delhi. Delhi Jal Board was responsible for procuring, processing, and distributing water in Delhi Municipal Corporation area (now divided into three corporations). It was also responsible for supplying bulk water to New Delhi Municipal Council and Delhi Cantonment Board. Moreover, it provides sanitation services in the entire city of Delhi.

Delhi Development Authority was set up by an act of Parliament in 1957. The DDA was made responsible for the planned and orderly development of the city-state by preparing master development plans. In addition to DJB, the DDA also formulates water policies and norms through successive master plans. When new areas are developed, the DDA declares them as "development areas" where it is responsible for building infrastructure and providing all utilities including water and sanitation services before handing over these areas to a municipality.

\section{IDENTIFYING AXES OF INFRASTRUCTURAL EXCLUSION IN DELHI}

Exclusion and denial both form part of infrastructural violence. Exclusion of the poor from accessing piped water occurs in multiple ways. In this section, we examine five dynamic forms of exclusion in current water infrastructure provision: legal exclusion; commodification and privatization; poor co-ordination; planning exclusion; and over-estimation of water supply.

\section{Infrastructural Violence Through Legal Exclusion}

A clear example of exclusion is illustrated within legislation governing water supply. The DJB is well aware that it underserves the poor and marginal groups. For example, DJB's internal note of 2004 concludes that "there is a need for targeted interventions to cater to the water and sanitation needs of the poor" (p. 8 as quoted in Sheikh et al., 2015). Rhetorical concern about the poor of Delhi is laudable. But in actual practice, Delhi Jal Board Act is openly discriminatory. For instance, section 9(1a) of the DJB Act 1998 says that DJB will not "provide water supply 
TABLE 2 | Population residing in informal settlements of Delhi, 2014.

\begin{tabular}{llc}
\hline S. No. & Type of informal settlement & Population \\
\hline 1. & Jhuggi Basti & $1,700,000$ \\
2. & Unauthorized colonies & $4,000,000$ \\
3. & Homeless and pavement dwellers & 16,000 \\
Total population residing in informal settlements & $5,716,000$ \\
Percent of total population & 33.62
\end{tabular}

Source: Planning Department, Government of NCT of Delhi (2019).

to any premises which have been constructed in contravention of any law ...."

Once unauthorized colonies and slums are regularized, the DJB becomes responsible for providing water in these areas. In non-notified slums, those slums that are deemed illegal occupation, the DJB has no obligation to provide water or sanitation services. However, under pressure from political leaders and courts, the DJB provides water to non-notified slums. But the main point is that legally speaking the DJB is not obliged to provide water to any illegally built residential areas, which include most of the unauthorized settlements and slums, where a large majority of Delhi residents live. The legislation governing water supply illustrates active infrastructural violence. The DJB has no legal obligation to provide water to non-notified or illegal occupations. However, this active violence is limited by the state to some extent through the provision of water and sanitation services to non-notified areas overlooking their illegalities. Provisions of the DJB Act 1998 clearly marginalize and exclude a large proportion of citizens living in Delhi from accessing water from the network (see Table 2). So, it can be argued that the water provisioning statute is exclusionary.

However, complications in this picture arise when enough political and legal pressure (through court verdicts) is exerted on the state bureaucracy that the same state stands with the citizens and ensures water provisioning through tankers and other means. Here, the state is simultaneously complacent in generating infrastructural violence by enacting laws to make such provisioning illegal, presumably with the intention of putting a stop to the spread of illegal developments. But when the state fails to contain illegal developments, it acts to limit infrastructural violence by temporarily providing water to thirsty populations. For example, on 31 August 2020, the Supreme Court ordered the removal of 48,000 slum clusters located within the safety zone of railway lines in Delhi. The Government of India informed the court through a submission by the Solicitor General that it was not possible immediately without exploring alternatives because over 200,000 families would be displaced if these people are evicted. One of the petitioners from the opposition party further noted: "Slum dwellers have a fundamental right to the city. They are an integral part of the social and economic fabric of the town... If the demolition of slums is carried out amidst the current pandemic, more than 250,000 persons will be forced to move around the city in search of shelter and livelihood" (The Hindu,
2020). Under such political pressure, infrastructure violence is temporarily put on hold and slum dwellers continue to access water and other services. This process of excluding the poor from potable water is therefore active violence as the state actively refuses to supply fixed infrastructure but transforms this into, passive violence because of the uncertainty of water provisioning provided through irregular and inequitable supply of water by tankers.

\section{Infrastructural Violence Through Commodification and Privatization}

If all else fails, one way to get access to potable water in Delhi is bottled water. The DJB and private vendors sell bottled water in Delhi. Millions of bottles of one liter or half a liter are served every day by private corporate vendors. However, what is most striking is the fact that the DJB sells $20-\mathrm{L}$ water canisters to private vendors who in turn sell them to households who cannot access potable water from any other source. They are generally poor people who either do not have access to water through the network because they are not connected or water through the network is insufficient for their basic needs.

The DJB's bottled water is expensive when compared with its piped water price per liter. For example, the starting tariff in Delhi is Rs $2.42 / \mathrm{kl}$ for piped water supply. Dwarka's middleclass residents pay Rs. 11/kl for piped supply and Rs. $47 / \mathrm{kl}$ for water supplied through tankers (Times of India, 2015). Corporate vendors sell $1 \mathrm{kl}$ of water in canisters to the poor at the steep rate of Rs. 2,600 (Delhi Jal Board, 2015), which is 236 times higher than water supplied through the network. Treating water as a commodity with an instrumental value alone excludes the most vulnerable. This system of water supply through 20 -L water canisters represents another example of active infrastructural violence, where infrastructure is designed to be violent through pricing (Desai, 2018). The way in which infrastructure is put together generates deprivations, inequities, conflicts, and denials.

Infrastructural violence also takes place through the privatization of the water supply. The Government of National Capital Territory of Delhi has made attempts to involve the private sector in selected areas with the objective of enhancing the level of water services, meaning making water available $24 \times 7$. The aim of the policy is to provide better services to those who can afford. This policy is meant to increase the level of service by providing $24 \mathrm{~h}$ piped water supply to residents with improved water infrastructure. This project includes Mehrauli and Vasant Vihar, which are largely high middle income and richclass areas (see Figure 1). To provide a better water supply, the MVV Water Utility Private Limited has been selected through a tendering process and tasked to improve the level of service in Mehrauli and Vasant Vihar. Work is awarded to a consortium of SPML Infra, Tahal Consulting Engineers and Hagihon Jerusalem Water and Wastewater Works (MVV), on Design,Build, Operate and Transfer basis by the DJB. The agreement to carry out this project was signed on 12 September 2012, some 9 years ago. The improved systems would be managed by the MVV for 2 years (MVV Water Utility Private Limited, 2013, p. 8). 

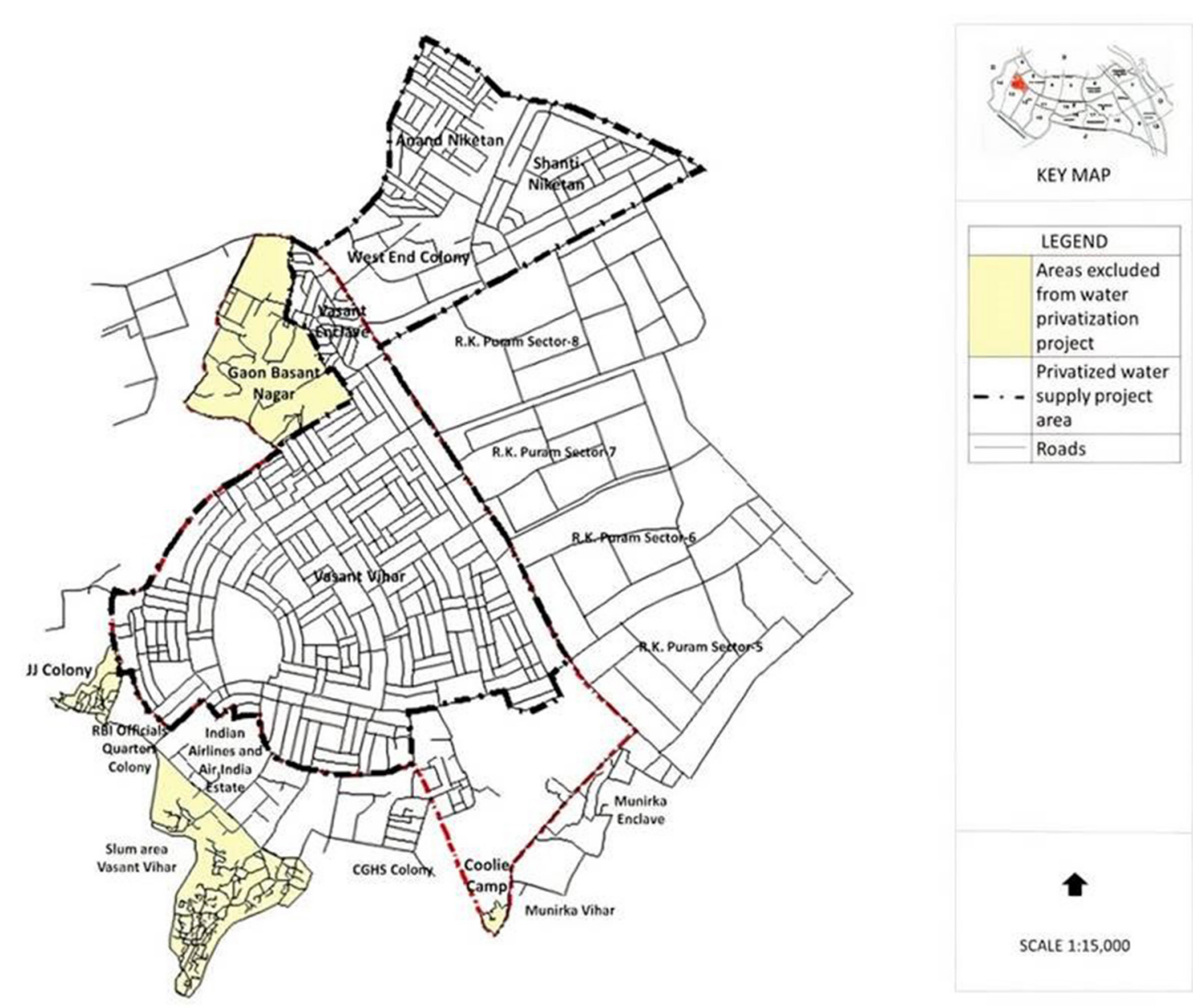

FIGURE 1 | Excluded areas from the project for enhancing level of service.

The President of the Vasant Vihar RWA gave consent to this project. With the World Bank loan of US\$ 224 million, it targeted 150,000 meter network and 500,000 populations with 200 LPCD target. Initially, the project with the support of the World Bank was initiated in 2002, and this project would have ended by 2005 and entire Delhi by 2015. Some scholars have likened this project of $24 \times 7$ water supply scheme in Vasant Vihar, southern Delhi to "exit the penury syndrome" (Ruet, 2007, p. 17). Exit the penury syndrome placed within the exclusionary global city narrative represents the Indian cities as spaces capable of sustaining higher standards of infrastructure provisioning and water supply services for specific classes.

Nevertheless, as we can see from Figure 1, this project deliberately excludes the poor areas shown in light yellow color on the edges of the project area. These areas are Coolie Camp, Slum Area Vasant Vihar, JJ Colony in the southern parts of the project site, and Gaon Basant Nagar in the eastern parts. Exclusion of these poor areas could not be seen more visibly, there is not even a pretense of inclusion. This is an episode of active infrastructural violence.

\section{Infrastructural Violence Through Lack of Coordination}

Passive infrastructural violence can also result from a lack of coordination between the DJB and the DDA. This can be seen by the Dwarka sub-city planning among other examples. Dwarka is a comprehensively planned new sub-city of $1,000,000$ population near the Indira Gandhi International airport. This large township was planned and built in the early 1990s by the DDA for the rising population of middle and elite groups. In the initial years, water was provided through 400 tankers twice a week. The DDA bought water in bulk from the DJB and provided it to the residents of Dwarka However full requirements could not be met through tankers due to their limited capacity (see Figure $\mathbf{2}$ for the location of the sub-city).

A relevant question is why no piped water was supplied for 15 years to the residents of Dwarka. The DJB officers tell us that the township was built without bothering to consult the DJB for water supplies. Dwarka got piped water supply from the DJB in February 2015 after nearly 15 years of the existence of the new town. Similarly, another DDA planned settlement 


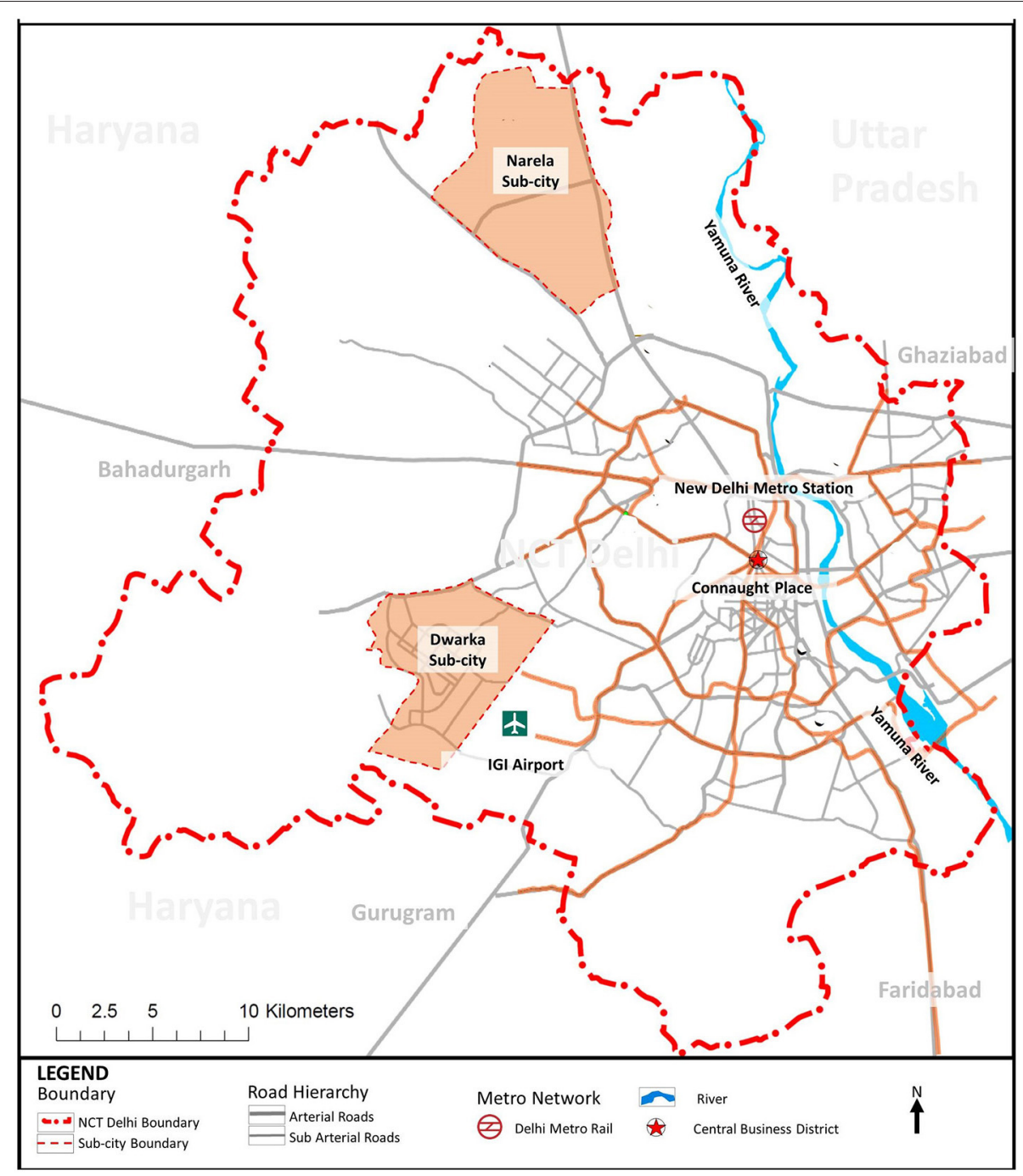

FIGURE 2 | Location of Dwarka and Narela sub-city in NCT of Delhi.

called Narela with a population of 225,000 does not have access to the piped water supply. As for Dwarka, until recently Narela got water supplies through tankers. The same pattern of violence caused through lack of coordination can be expected to continue as the DJB has not been consulted for the recently approved Land Pooling Policy 2013, which would result in 1.7 million housing units in the near future (Master Plan for Delhi-2021, Delhi Development Authority, 2007) with little consideration of water supply.

Failure of coordination among agencies with different responsibilities falling under different legislations is a cause of infrastructural violence against all income classes through exclusion from networked water supplies for many years. Planning and development of new townships in Delhi appear to proceed without careful consideration of supply of potable water. Even middle-class residents have to rely on water provided through tankers. Water networks become operational only after several years of township development.

\section{Infrastructural Violence via City Planning}

Passive infrastructural violence is also illustrated in the city's planning system seen by studying the various versions of the master plans of Delhi. The inequitable intent of the city planning agency is highly visible through the three Master Plans of 1981, 2001, and 2021.

The first Master Plan for Delhi ${ }^{1}$ was prepared by the DDA with the help of the Ford Foundation team led by Albert Meyer and came into force in 1962. This plan had the horizon year

\footnotetext{
${ }^{1}$ Master Plan for Delhi is a physical development plan for the city. It has two parts, one containing city planning policies and the other planning norms and standards. The document is supported by a land use map for the horizon year, effectively proposing how land would be used in the next 20 years.
} 
of 1981. In the Plan, while work studies were comprehensive, it only spared one paragraph for water policy, giving little space and thought to water planning. After we closely examined the Master Plan for Delhi, 1981, and associated work studies, we made several interesting discoveries.

The DDA divided Delhi into three parts: Class A: Delhi Urban Area; Class B: Ghaziabad, Faridabad, and Ballabgarh; Class C: Gurgaon, Bahadurgarh, Narela, and Loni. These three settlement classes are based on location, stage of development, and population. The master plan policy clearly suggests that central place with large population (Delhi Urban Area) where the most powerful politicians and bureaucrats reside, deserves more water than smaller towns located on the periphery of the metropolis. So, the DDA proposed different water supply standards and different times for supply of water to these areas. The standard of water supply for Class A i.e., Delhi Urban Area was set at 50 gallons per capita per day. The standard for Class B including Ghaziabad, Faridabad, and Ballabgarh was set at 45 gallons per capita per day and for Class C i.e., Gurgaon, Bahadurgarh, Narela, and Loni, at that time upcoming future towns, the standard was set at a much reduced rate of 35 gallons per capita per day. The Master Plan for Delhi, 1981 also proposed that water will be supplied in Delhi and the Ring Towns with different time durations. For Class A i.e., Delhi Urban Area, the planning agency intended to supply water for $24 \mathrm{~h}$. However, in practice, it was found that water could be supplied only for $18 \mathrm{~h}$. In Class B towns such as Ghaziabad, Faridabad, and Ballabgarh, the intent of the planning agency was to supply water for $18 \mathrm{~h}$. But it could supply water in these areas only for $16 \mathrm{~h}$. In Class $\mathrm{C}$ areas i.e., Gurgaon, Bahadurgarh, Narela, and Loni water was proposed and supplied for $12 \mathrm{~h}$ (Delhi Development Authority, 1981; also see Table 4).

Moreover, the availability of water determined the growth potential and economic significance of various ring towns, towns located around Delhi. Ghaziabad was the most populated town with a total population of 357,000 in 1981 and it was envisaged as an industrial town with 50,000 workers in manufacturing work. Similarly, Faridabad, Ballabgarh towns of Haryana state and Loni and Narela towns in Delhi had strong manufacturing units. Water requirements of these two adjacent towns were expected to be met easily by tube wells and good underground water resources. However, due to the absence of good water resources, the development and growth of Gurgaon and Bahadurgarh towns were expected to be low (Delhi Development Authority, 1981). The act of leaving behind certain ring towns in the plan due to low water resources instead of the plan facilitating equitable growth is in itself a form of active infrastructural violence.

This practice of making essential services like water supplies available in different areas for different time durations and with different standards is exclusionary at its root. Mostly, people living in the periphery of the city would get reduced amounts of water for reduced time periods (also see Table 4). Heavy reliance on government framed norms appears to be the most probable reason for different standards for different areas. Like the colonists, elected governments have also provided more water per capita per person to people living in or close to the seat
TABLE 3 | Water supply variations in different areas of Delhi, 1999-2018.

\begin{tabular}{llcc}
\hline Area category & $\begin{array}{l}\text { Name of the } \\
\text { area }\end{array}$ & $\begin{array}{c}\text { Water supply } \\
\text { norm, 1999 } \\
\text { (LPCD) }\end{array}$ & $\begin{array}{c}\text { Water supply } \\
\text { norm, 2018 } \\
\text { (LPCD) }\end{array}$ \\
\hline $\begin{array}{llcc}\text { Comprehensively } \\
\text { planned }\end{array}$ & NDMC & 462 & 440 \\
& $\begin{array}{l}\text { Delhi Cantonment } \\
\text { Board Area }\end{array}$ & 509 & 509 \\
& New Delhi and & 148 & 228 \\
& South Delhi & & \\
& Civil Lines and & 274 & 228 \\
& Rohini & & \\
& Shadhara & 130 & 228 \\
& West Delhi & 202 & 228 \\
Unplanned/Old & Old Delhi & 277 & - \\
city & Karol Bagh & 337 & - \\
Outer Delhi & Pahar Ganj & 201 & 40 \\
& Narela & 31 & 40 \\
& Najafgarh & 74 & 228 \\
& Dwarka & 74 & 40
\end{tabular}

Source: Delhi 1999-A Fact Sheet NCRPB; Planning Department, Government of NCT of Delhi (2019) and Delhi Jal Board (2016).

TABLE 4 | Different time durations and different standards of water supply, 2007.

\begin{tabular}{|c|c|c|}
\hline $\begin{array}{l}\text { Class A-Delhi } \\
\text { (Delhi Urban Area) }\end{array}$ & $\begin{array}{l}\text { Class B-Ring Towns } \\
\text { (Ghaziabad, Faridabad, } \\
\text { Ballabgarh) }\end{array}$ & $\begin{array}{l}\text { Class C-Ring Towns } \\
\text { (Gurgaon, Bahadurgarh, } \\
\text { Narela, Loni) }\end{array}$ \\
\hline $\begin{array}{l}\text { Per capita supply } 50 \\
\text { gallons }\end{array}$ & $\begin{array}{l}\text { Per capita supply } 45 \\
\text { gallons }\end{array}$ & Per capita supply 35 gallons \\
\hline 24 h supply per day & $16 \mathrm{~h}$ supply per day & 12 h supply per day \\
\hline $\begin{array}{l}\text { Must supply } \\
\text { between } 4 \text { a.m. and } \\
10 \text { p.m. }\end{array}$ & $\begin{array}{l}\text { Continuous supply from } \\
4 \text { a.m. to } 10 \text { p.m. }\end{array}$ & $\begin{array}{l}\text { Continuous supply 5-11 a.m. } \\
\text { and } 4-10 \mathrm{pm} \text { in domestic } \\
\text { areas, major industries should } \\
\text { meet their requirements from } \\
\text { tube wells }\end{array}$ \\
\hline \multirow[t]{2}{*}{-} & $\begin{array}{l}\text { Sources to be ground } \\
\text { water, infiltration galleries, } \\
\text { and wells }\end{array}$ & $\begin{array}{l}\text { Sources to be tube wells, } \\
\text { infiltration wells to avoid } \\
\text { mechanical treatment }\end{array}$ \\
\hline & $\begin{array}{l}\text { Major industry should } \\
\text { meet their requirement } \\
\text { from bore to small size } \\
\text { tube well }\end{array}$ & $\begin{array}{l}\text { Road washing, horticulture } \\
\text { from local wells and ponds }\end{array}$ \\
\hline
\end{tabular}

Source: Compiled by the authors from Master Plan for Delhi (2021).

of power. New Delhi Municipal Council gets more water than any other area (Hosagrahar, 2005, 2010; Sharan, 2006; also see Table 3).

The next version of the Master Plan for Delhi was enforced in 1990 with the time horizon of 2001. Based on self-devised norms, this development plan proposed a uniform standard of water supply at the rate of 80 gallons per capita per day throughout Delhi. Out of 80 gallons per capita per day, 50 gallons per capita per day was meant for drinking purposes throughout Delhi. Ring 


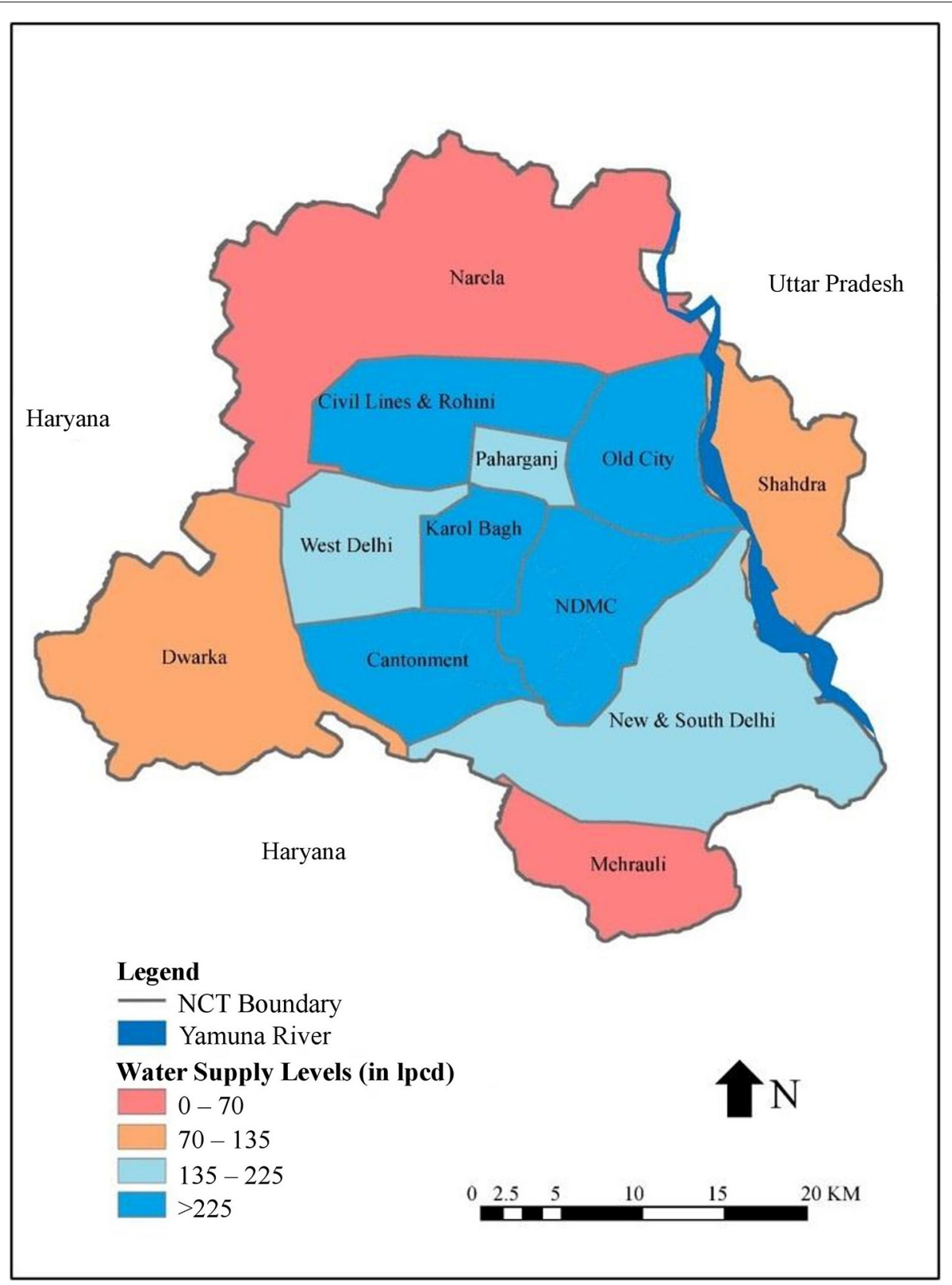

FIGURE 3 | Water inequities in Delhi, 1999.

towns $^{2}$ were not discussed in this plan, probably because the Regional Plan, 2001 was notified in 1989. Additionally, DDA being the land owning agency in Delhi, allocated land to the DJB for building water treatment plants and sewage treatment plants. Although it was an improvement over the previous master plan, and a high standard of water supply was set for domestic purposes, inequities in water supply persisted.

Analysis of the Master Plan for Delhi 2001 revealed that the development plan was highly aspirational in terms of high-end

${ }^{2}$ Towns located around Delhi and forming a ring are called ring towns. developments like building malls, middle class, and elite housing, but did not take into account the important issue of inequities of water in Delhi as not a single word was written in the plan on equitable distribution of water among various types of areas and populations. Due to this limitation, the Master plan policies and DJB policies on water could not eliminate water inequities in the city and remained inherently violent (see Figure 3). As the map shows, clearly, inner areas receive more water per person per day than peripheral areas. Some areas like the NDMC receive nearly $500 \mathrm{~L}$ of water per person per day in comparison to other areas only receiving $25 \mathrm{~L}$ per person per day. So far, the 
planning agency's focus remained on aggregate water production and distribution, and also on setting high water supply standards.

Elite areas like New Delhi Municipal Council and Delhi Cantonment buy water in bulk and therefore these areas do not form part of DJB's water zones. However, areas located in central parts of the city like Old Delhi and Karol Bagh receive considerably higher amounts (over 250 LPCD) of water. These areas are located in Northwest IV, Central I and Central II zones of the DJB. Similarly, Civil Lines and Rohini, two high income planned areas, also receive higher amounts of daily water supplies and they are located in North West I, part of North West II, and part of West III. West Delhi, New Delhi and South Delhi are also inhabited by high and middle income groups and receive moderately higher amounts (135-225 LPCD) of water. These three areas are located in South West I and II, West I, South I to IV and South West III zones. Narela is located in the DJB's North West II, North I and West III while Mehrauli is located in South I zone. Both Narela and Rohini house low income resettlement areas and receive lower quantities of daily water supplies. Shadhara is located in the DJB's North East I and II, East I and East II zones. This area receives comparatively less amounts of daily water compared to the central parts of the city as most of its residents belong to middle income and low income groups. Dwarka, a planned sub-city located in South West I and II zones of the DJB, receives moderate quantities of water for daily use. As we move away from the city center, daily water supplied to residents living in different zones also reduces and least amount of water is supplied in resettlements areas (read Figure 3 with Table 1).

Trying to find a middle ground, the DDA ended up providing a high standard of water supply at the rate of 45 gallons per capita per day in its Master Plan for Delhi 2021, which was enforced on 7 February 2007. The plan argues that there is a need for capacity building through the principle of "user pays approach" and this policy should be implemented through public-private partnerships. This is very typical of the mainstream international language on the water in this period based on the neoliberal approach to service delivery. Commodification and privatization are central to this plan when neoliberal economic and political thinking took the center stage after structural economic reforms (Hope et al., 2013; see Mohan, 2017). Privatization of potable water was also seen in the Plan through the Land Pooling Policy 2013 by the DDA. This policy handed over future development to the private sector, which gives further credence to the continued inequitable and violent distribution of potable water.

The plan also emphasized that there is a need to improve efficiency through better community participation and decentralized management. Promoting efficiency further, the plan also proposed that the percent of non-revenue water should be reduced as the estimated water losses stand at $40 \%$. The plan was also concerned about water conservation through an integrated community-driven model. To pursue this line of thinking, the DDA made proposals for making amendments to the Delhi Water Board Act, 1998. However, it should be noted that the DJB itself is responsible for the largest proportion of the non-revenue water. Moreover, it is estimated that the planned areas, due to faulty meters, are the next highest contributors to the non-revenue water after the DJB (Comptroller and Auditor General of India, 2013). However, the informal settlements are the ones who are blamed and targeted by various governmental agencies and the middle class and elite for the alleged theft of water (Truelove, 2018). This can be seen in past communitydriven models which were meant to serve the middle classes and penalized the informal settlements (Truelove and Mawdsley, 2011, p. 419). As a result, while improving the efficiency by reducing non-revenue water through community-driven models is commendable, it targets the already most marginalized.

The Master Plan for Delhi 2021 acknowledges water inequities but provides no mechanisms to reduce them because of its entire focus on efficient production and distribution of potable water in line with the central government's neoliberal economic policies. There is no word on balancing efficiency with equity in the plan. In fact, as discussed above, DDA does not acknowledge the existence of slum areas as they are regarded as an illegal occupation on public lands and so deserve demolition. In the Master for Delhi, 2021, the approach to water planning changed from water provisioning to water management with an emphasis on water commodification and privatization. However, water inequities continue to persist enabling the continuation of infrastructural violence.

Furthermore, the DDA has outsourced the preparation of the Master Plan for Delhi, 2041 to a central government controlled urban studies research organization, the National Institute of Urban Affairs. Considering that this agency has neoliberal leanings in line with the controlling Ministry of Housing and Urban Affairs, it is expected that the plan will say less on the removal of inequities and more on the commodification of water.

\section{Infrastructural Violence via Over-estimation of Actual Water Supply}

Overestimation causes passive infrastructural violence by hiding inequalities, first, of the quantity of water supplied and second, about irregularities within the extraction of non-revenue water. The DJB measures its success in terms of aggregate water supplied from all the treatment plants rather than the number of people who receive adequate, affordable, and quality water regularly. Moreover, non-revenue water or the water lost during distribution too is calculated in absolute terms. As a result, water shortages faced by informal settlements, both due to low water supply by the state and loss of water due to extraction in large quantities by actors such as industries, remain hidden.

In 2013, the Comptroller and Auditor General of India (CAG) through its comprehensive audit found that the DJB lacked an information system to collect and analyse data on water production and distribution of potable water. The auditors argued that the DJB looks at the total treated raw water per day as the total installed capacity of its treatment plants in Delhi and then divides by the current population, theoretically obtaining per capita per day water produced. Water treatment plants are assumed to be working at $100 \%$ capacity. For example, the installed capacity of all water treatment plants in Delhi is estimated to be 833 million gallons per day (MGD), and if this 
is divided by Delhi's population of nearly 17 million, it gives a figure of $200 \mathrm{~L}$ per person per day (Truelove, 2018, p. 8-10). But this figure is notional because one does not know how much water came into treatment plants and how much water reached each district, household, or industry. The DJB also cannot tell with any certainty how much water is actually distributed to the residents connected with the network because it does not have systems like functional pump meters in district metering areas. Moreover, the available water is pulled using electric motors by the underserved middle-class residents. Their ability to fulfill the shortages by technical solutions causes direct violence to the informal settlements by pulling water away from them.

Most importantly, over $40 \%$ of the total water is estimated to be non-revenue water i.e., water lost during distribution. A hidden distributive injustice and violence masks the differential allocations of water in practice. For example, due to overextraction by influential consumers like the industry or private tankers, less water per person reaches a majority of the networked but poor populations. As a result, as discussed above, informal settlements must pay for this loss of water by being unproportionately fined for illegal extraction and through getting reduced water supply.

In the absence and irregularity of all this information, it is an erroneous calculation that the DJB supplies water at the rate of $200 \mathrm{~L}$ per person per day. Truelove (2018) argues that water inadequacies and exclusions are erased through deliberate overestimation of water production, a form of active violence.

\section{DISCUSSION}

We have explored five axes of infrastructural exclusion in the water supply of Delhi in the contemporary period. Through the conceptual lens of infrastructural violence, we have argued that the combination of legal statutes, commodification and privatization of water, and infrastructure planning decisions all constitute active forms of infrastructural violence.

Second, infrastructural violence expresses spatialization of injustices through the use of state/elite power. Here, exploring the historical context of how "people, materials, and territories have been controlled and organized" is important to understand the context and flows of power. Hawkins (2014, p. 300) explores the formation of the state over the years, and concludes that state sustains elite power and draws on elite power to maintain and enhance state power and capacity. This epitomizes the notion of "infrastructural power" as stated by Mann (1984) when referring to the development and manipulation of infrastructure to uphold dominant social class structures in order to suppress the lower classes (Rodgers and O'Neill, 2012, p. 404). A poignant example is discussed by both Hawkins (2014) and Tarrow (2018) who show the central role of a country's security, and the necessity of the state to hold political power over the military by controlling resources. So, it is possible to sustain and strengthen state power/elite power by designing and provisioning infrastructure in specific ways. We could therefore argue that the state and infrastructural violence normally go together.

Third, the historical perspective, of the organization of water supply within both Mughal and British colonial eras, provides context and credence to the acceptance and normalization of division and inequity we witness today at the political, legal, economic, social, and technical levels of water supply. The paper has shown that the historical continuity of water inequities has enabled the displacement of a water equity agenda.

Fourth, infrastructural violence, among other things, is a class phenomenon. The objective of provisioning water services

TABLE 5 | Forms of water infrastructural violence.

\begin{tabular}{|c|c|c|c|c|}
\hline S. no. & Elements & Description & Consequences & $\begin{array}{l}\text { Infrastructural } \\
\text { violence }\end{array}$ \\
\hline 1. & $\begin{array}{l}\text { Legal infrastructural } \\
\text { violence }\end{array}$ & $\begin{array}{l}\text { When statutory provisions actively consider } \\
\text { water provisioning to illegally built areas beyond } \\
\text { their responsibility. }\end{array}$ & $\begin{array}{l}\text { People living in non-notified un-authorized areas } \\
\text { and slums get excluded from provisioning of water } \\
\text { by the DJB. }\end{array}$ & $\begin{array}{l}\text { Active infrastructural } \\
\text { violence }\end{array}$ \\
\hline 2. & $\begin{array}{l}\text { Infrastructural violence } \\
\text { via planning }\end{array}$ & $\begin{array}{l}\text { The DJB provides water at different rates and } \\
\text { time durations. }\end{array}$ & $\begin{array}{l}\text { Peripheral and comparatively low income areas and } \\
\text { populations get less water per person per day. }\end{array}$ & $\begin{array}{l}\text { Passive } \\
\text { infrastructural } \\
\text { violence }\end{array}$ \\
\hline 3a. & $\begin{array}{l}\text { Infrastructural violence } \\
\text { through } \\
\text { commodification }\end{array}$ & $\begin{array}{l}\text { A new water supply system is built to exclude } \\
\text { the poor and marginalized populations. }\end{array}$ & $\begin{array}{l}\text { Inadequate access to potable water, for example, } \\
20 \mathrm{~L} \text { water canisters are being supplied by private } \\
\text { vendors. }\end{array}$ & $\begin{array}{l}\text { Active infrastructural } \\
\text { violence }\end{array}$ \\
\hline 3b. & $\begin{array}{l}\text { Infrastructural violence } \\
\text { through privatization }\end{array}$ & $\begin{array}{l}\text { Level of water service to be enhanced for the } \\
\text { middle income and elite groups. }\end{array}$ & Exclusion of the poor areas and populations. & $\begin{array}{l}\text { Active and passive } \\
\text { infrastructural } \\
\text { violence }\end{array}$ \\
\hline 4. & $\begin{array}{l}\text { Infrastructural violence } \\
\text { through lack of } \\
\text { coordination }\end{array}$ & $\begin{array}{l}\text { The planning agency and water supply agency } \\
\text { fail to coordinate. }\end{array}$ & $\begin{array}{l}\text { The DDA developed planned areas get excluded } \\
\text { from water supplies. }\end{array}$ & $\begin{array}{l}\text { Passive } \\
\text { infrastructural } \\
\text { violence }\end{array}$ \\
\hline 5. & $\begin{array}{l}\text { Infrastructural violence } \\
\text { via over-estimation }\end{array}$ & $\begin{array}{l}\text { Total treated water from all WTPs is assumed } \\
\text { to have been supplied to individuals and } \\
\text { households. Water supply calculations are } \\
\text { based on erroneous assumptions. }\end{array}$ & $\begin{array}{l}\text { On average one may arrive at a decent supply per } \\
\text { person per day. On the ground poor people lose out } \\
\text { and get little water as nearly half the water is lost } \\
\text { (stolen) during distribution. }\end{array}$ & $\begin{array}{l}\text { Passive } \\
\text { infrastructural } \\
\text { violence }\end{array}$ \\
\hline
\end{tabular}


to high income groups not only excludes slum dwellers from piped water networks; it also inflicts infrastructural violence by proportionately reducing quality as well as quantity of water supplied to them via disconnection (see Table 1). A discussion on exclusions alone does not sufficiently focus on violent policy outcomes. For instance, in the case of water supply in Delhi, it assumes away bad intentions of water provisioning in illegally built areas without debating contextual factors such as poverty that led to illegal occupation of public lands by the urban poor. Exclusions pay no attention to the failure of implementation of planning policies to build affordable housing because of which the poor have to live in slums with little access to infrastructure.

Fifth, infrastructural violence based on commodification and privatization of water is also ideological. In the present times, neoliberalism is the dominant paradigm of planning and development promoting marketization and its supporting institutional scaffolding. Delhi like many cities worldwide has joined the race for global recognition under the influence of neoliberal ideology, which seeks to promote unfettered markets, free flows of capital, and "discourses of symbolic formations arranged around [such] persuasive political ideas" (Ahmed, 2011, p. 164). Cities being the mainstay of wealth creation, this ideological shift has resulted in the accentuation of poverty, inequality, and class divisions in Delhi as governments continue to focus on profit maximization (Ghosh, 2020).

Sixth, cultural practices such as an entrenched caste system and gender norms work in combination with the dominant neoliberal economic ideology to enable the elite to maintain control over the state. In turn, unaccountable governments and religious identity based discriminations continuously reproduce infrastructural violence. Discriminatory ideologies are thus performed and enacted through water policies, plans, laws, and practices via the exercise of state/ elite power.

Seventh, blurred lines of accountability is an important attribute of infrastructural violence. Blurring due to lack of credible information in the public sphere likely shapes infrastructural violence as it reduces the possibility of fixing responsibility and accountability of water providers. With the case of Tanzania, Mdee and Thorley (2016) argue that trying to unpack lines of blame for service delivery failure is a necessary first step to any possibility of accountability. In the case of Delhi, infrastructural violence is also inflicted via over-estimation of potable water supplied per person per day, which is based on problematic and limited calculations.

Finally, a lack of transparency and a culture of secrecy perpetuates infrastructural violence as these acts reduce accountability and fixing of responsibility becomes difficult. Data on the water provisioning system in Delhi is highly secretive and sharing data with researchers is limited and the data is ambiguous. As Truelove (2018, p. 1) underscores, secrecy and ambiguity underpins political abuse. However, pinning responsibility on particular organizations and individualsthe primary goal of attempting to understand infrastructural violence-is perplexing because the "very nature of the scale, pace and in a conceptual space from which infrastructure develops support in the difficulty in attributing blame and responsibility" (Rodgers and O’Neill, 2012, p. 402). Another difficulty about attribution of policy consequences is that all outcomes are not planned in advance. Deeper investigations through the lens of infrastructural violence help us in shedding light on the questions of sustainability and perpetuation of accountable water provisioning systems by treating infrastructure as more than physical collection of technologies (Amin, 2014; also see Table 5).

We assert that our five identified axes exclusion in water supply also underpin the wider dynamics of infrastructural violence. We end this section with a summary of the five axes observed in Delhi in Table 5.

\section{CONCLUDING REMARKS}

Centered on five axes of exclusion, this paper delineates the contours of infrastructural violence in the provisioning of potable water in Delhi. We argue that infrastructural violence takes place due to five exclusions suffered by the most marginalized groups of population living in slums. To a great extent responsibility for these exclusions can be pinned on the state through design of policies, plans, statutes, and cultural practices. Clearly showing the workings of the five dimensions of infrastructural violence, we have provided evidence for both historical roots and contemporary dynamics of exclusions' based on infrastructural violence.

Historical legacies of colonialism have set the stage for fragmented provision of water supplies to people of different social identities and economic classes. The conditions created by the colonists historically prevented the poor and lower castes from accessing good quality water. Post-colonial democratic governments have followed similar policies in the absence of low levels of public accountability. Lack of transparency and rent seeking behavior of government servants has further made it nearly impossible to have better access to safe water. Of course, the same water systems serve middle and elite classes (the civil society) very well because of their influential civic agency (Chatterjee, 2004, p. 38; also see Chaplin, 2011). Unjust water laws such as the Delhi Jal Board Act, 1998 are brutally violent, particularly through their avoidance of responsibility for residents living in slums. Instead of addressing this inequity, the process of backdoor privatization, justified through a narrative of enhancing level of service, reinforces historical dynamics of exclusion. Commodification of water by the DJB, leading to the sale of bottled water, among others, to people living off the network promulgates active infrastructural violence. Bottled water produced by the DJB and sold to the poor through private vendors is violent in design.

Building on the theoretical framework of "infrastructural violence," our analysis has shown that policies and laws have persistently contained elements of infrastructural violence. More recent enabling policies of the neoliberal state have 
only accentuated infrastructural violence and increased inequality. Untangling these exclusions will not be easy and requires extensive reforms including political willingness, and institutional capability.

\section{DATA AVAILABILITY STATEMENT}

The original contributions presented in the study are included in the article/supplementary materials, further inquiries can be directed to the corresponding author/s.

\section{REFERENCES}

Adve, N. (2004). No Space for Delhi's Poor. India Resource Center. Available online at: http://www.indiaresource.org/issues/globalization/2004/ nospacefordelhipoor.html (accessed July 3, 2020).

Ahmed, W. (2011). Neoliberal utopia and urban realities in Delhi. ACME Int. E. J. Crit. Geograph. 10, 163-188. Available online at: https://www.acme-journal. org/index.php/acme/article/view/893/749

Amin, A. (2014). Lively infrastructure. Theory Cult. Soc. 31, 137-161. doi: $10.1177 / 0263276414548490$

Anderson, M. (2011). Public Nuisance and Private Purpose: Policed Environments in British India, 1860-1947. SOAS School of Law Research Paper, 5.

Baviskar, A. (2019). Between violence and desire: space, power, and identity in the making of metropolitan Delhi. Int. Soc. Sci. J. 68, 199-208. doi: $10.1111 /$ issj. 12184

Baviskar, A. (2020). Uncivil City: Ecology, Equity and the Commons in Delhi. New Delhi: Yoda Press, Sage.

Bentinck, J. (2000). Unruly Urbanisation on Delhi's Fringe: Changing Patterns of Land Use and Livelihood. Groningen: University of Groningen Press; Barkhuis.

Bhan, G. (2016). In the Public's Interest: Evictions, Citizenship, and Inequality in Contemporary Delhi. Athens, GA: University of Georgia Press.

Bhan, G., and Shivanand, S. (2013). (Un) settling the city: analysing displacement in Delhi from 1990-2007. Econ. Polit. Week. 48, 54-61. Available online at: https://www.epw.in/journal/2013/13/reviewurban-affairs-review-issues/unsettling-city.html?0=ip_login_no_cache \%3D91046ffa21bbea83c440fbf1a824ead2

Biswas, D. (2020). Navigating the city's waterscape: gendering everyday dynamics of water access from multiple sources. Dev. Pract. 31, 248-258. doi: $10.1080 / 09614524.2020 .1836128$

Bora, R. S. (2014). Migrant informal workers: a study of delhi and satellite towns. Mod. Econ. 5, 562-579. doi: 10.4236/me.2014.55053

Broich, J. (2007). Engineering the empire: British water supply systems and colonial societies, 1850-1900. J. Brit. Stud. 46, 346-365. doi: 10.1086/510891

Chaplin, S. E. (2011). Indian cities, sanitation and the state: the politics of the failure to provide. Environ. Urban. 23, 57-70. doi: 10.1177/0956247810396277

Chatterjee, P. (2004). The Politics of the Governed: Reflections on Popular Politics in Most of the World. New York, NY: Columbia University Press.

Comptroller and Auditor General of India. (2013). Report of Comptroller and Auditor General of India on Social Sector (Non-PSU) for the Year Ended 31 March 2012. New Delhi: CAG.

Delhi Administration. (1976). Delhi Gazetteer. New Delhi: Ministry of Information and Broadcasting.

Delhi Development Authority. (1981). Master Plan for Delhi-1981. New Delhi: Delhi Development Authority.

Delhi Development Authority. (2007). Master Plan for Delhi-2021. New Delhi: Delhi Development Authority.

Delhi Jal Board (2015). Delhi Jal Boards Packaged Drinking Water Bottling Plant. Delhi Jal Board; Government of NCT of Delhi. Available online at: http:// delhijalboard.nic.in/content/Drinking-Water

Delhi Jal Board (2016). Draft Water Policy for Delhi. New Delhi: Delhi Jal Board. Available online at: http://delhijalboard.nic.in/content/draft-waterpolicy-delhi

\section{AUTHOR CONTRIBUTIONS}

All authors listed have made a substantial, direct and intellectual contribution to the work, and approved it for publication.

\section{FUNDING}

This research work is supported by Water Security and Sustainable Development Hub which is funded by the UK Research and Innovation's Global Challenges Research Fund (GCRF), grant number: ES/S008179/1.

Desai, R. (2018). Urban planning, water provisioning and infrastructural violence at public housing resettlement sites in Ahmedabad, India. Water Altern. 11, 86-105. Available online at: https://www.water-alternatives.org/index.php/ tp1-2

Dupont, V. (2004). Socio-spatial differentiation and residential segregation in Delhi: a question of scale? Geoforum 35, 157-175. doi: 10.1016/j.geoforum.2003.08.003

Dupont, V. (2008). Slum demolitions in Delhi since the 1990s: an appraisal. Econ. Polit. Week. 43, 79-87. Available online at: https://www.epw.in/journal/2008/ 28/special-articles/slum-demolitions-delhi-1990s-appraisal.html

Dupont, V. (2011). The dream of Delhi as a global city. Int. J. Urban Region. Res. 35, 533-554. doi: 10.1111/j.1468-2427.2010.01027.x

Fernandes, L. (2006). India's New Middle Class: Democratic Politics in an Era of Economic Reform. Minneapolis, MN: University of Minnesota Press.

Fischer-Tine, H., and Mann, M. (eds.). (2004). Colonialism as Civilising Mission, Cultural Ideology in British India. London: Anthem Press.

Ghertner, A. D. (2015). Rule by Aesthetics: World-Class City Making in Delhi. New Delhi: Oxford University Press. doi: 10.1093/acprof:oso/9780199385560.001.0001

Ghosh, S. (2020). Understanding homelessness in neoliberal city: a study in Delhi. J. Asian Afr. Stud. 55, 285-297. doi: 10.1177/0021909619875775

Gooptu, N. (2001). The Politics of the Urban Poor in Early TwentiethCentury India, Vol. 8. Cambridge University Press. doi: 10.1017/CBO97811392 52256

Government of the National Capital Territory of Delhi. (2019). Economic Survey of Delhi 2019-20. Delhi: Planning Department, Government of the National Capital Territory of Delhi.

Graham, S. (2004). "Constructing urbicide by bulldozer in the occupied territories," in Cities, War, and Terrorism: Towards an Urban Geopolitics, ed S. Graham (Oxford: Blackwell), 192-213. doi: 10.1002/9780470753033.ch11

Graham, S. (2006). "Urban metabolism as target: contemporary war as forced demodernization," in In the Nature of Cities: Urban Political Ecology and the Politics of Urban Metabolism, eds N. Heynen, M. Kaika, and E. Swyngedouw (London: Routledge), 245-265.

Graham, S. (2010). Disrupted Cities: When Infrastructure Fails. London: Routledge. doi: $10.4324 / 9780203894484$

Gupta, N. (1981). Delhi Between Two Empires, 1803-1931. New Delhi: Oxford University Press.

Hameed, Y. (2017). Master plans and patterns of segregation among muslims in Delhi. Crit. Plann. 23, 101-127. doi: 10.5070/CP8231038130

Hardiman, D. (2002). The politics of water in Colonial India. South Asia J. South Asian Stud. 25, 111-120. doi: 10.1080/00856400208723477

Hawkins, J. R. (2014). Historicizing the state in development theory: Michael Mann's model of social power. Prog. Dev. Stud. 14, 299-308. doi: $10.1177 / 1464993414521333$

Hope, N.C., Kochar, A., Noll, R., and Srinivasan, T.N. (eds.). (2013). Economic Reform in India. New Delhi: Cambridge University Press. doi: 10.1017/CBO9781139096638

Hosagrahar, J. (2005). Indigenous Modernities: Negotiating Architecture and Urbanism. New York, NY: Routledge.

Hosagrahar, J. (2010). "Landscapes of water in Delhi: negotiating global norms and local cultures," in Megacities: Urban Form, Governance, and 
Sustainability, eds A. Sorensen and J. Okata (Singapore: Springer), 111-132. doi: 10.1007/978-4-431-99267-7_6

Jadhav, N. (2003). Untouchables. New York, NY: Scribner.

Kishore, R. (2015). Urban 'failures': municipal governance, planning and power in colonial Delhi, 1863-1910. Ind. Econ. Soc. Hist. Rev. 52, 439-461. doi: $10.1177 / 0019464615603895$

Kumar, A. (2014). Access to basic amenities: aspects of caste, ethnicity and poverty in rural and urban India-1993 to 2008-2009. J. Land Rural Stud. 2, 127-148. doi: $10.1177 / 2321024913515113$

Kumar, A. (2020). "The right to centrality and discursive articulations: a case of city planning policies in Delhi," in The Politics of Social Inclusion: Bridging Knowledge and Policies Towards Social Change, eds G. Koehler, A. D. Cimadamore, F. Kiwan, and P. M. M. Gonzalez (New York, NY: Columbia University Press), 223-254.

Kumar, A., Vidyarthi, S., and Prakash, P. (2021). City Planning in India: 1947-2017. New York, NY: Routledge. doi: 10.4324/9781003055969

Mann, M. (1984). The autonomous power of the state: its origins, mechanisms and results. Eur. J. Sociol. 25, 185-213. doi: 10.1017/S0003975600 004239

Mdee, A., and Thorley, L. (2016). Good Governance, Local Government, Accountability and Service Delivery in Tanzania: Exploring the Context for Creating a Local Governance Performance Index, Working Paper 2. London: ESRC.

Ministry of Water Resources, Government of India (2002). National Water Policy. New Delhi: Ministry of Water Resources. Available online at: http://jalshaktidowr.gov.in/policies-guideline/policies/national-water-policy

Ministry of Water Resources, Government of India. (2012). National Water Policy. New Delhi: Ministry of Water Resources.

Mohan, R. (2017). India Transformed: 25 Years of Economic Reforms. New Delhi: Penguin Books.

MVV Water Utility Private Limited. (2013). Implementation Plan for Improvement in Service Level for Water Supply in Mehrauli and Vasant Vihar Area, New Delhi, India. New Delhi: MVV Water Utility Private Limited.

NSO. (2018). Drinking Water, Sanitation, Hygiene and Housing Condition in India. National Statistical Office, Ministry of Statistics and Programme Implementation, Government of India, New Delhi.

Planning Department, Government of NCT of Delhi (2019). Economic Survey of Delhi 2018-19. New Delhi: Planning Department. Available online at: http:// delhiplanning.nic.in/content/economic-survey-delhi-2018-19

Rodgers, R., and O’Neill, B. (2012). Infrastructural violence. Ethnography 13, 401-412. doi: 10.1177/1466138111435738

Roy, A. (2011). "The blockade of the world-class city: dialectical images of Indian urbanism," in Worlding Cities, Asian Experiments and the Art of being Global, eds A. Roy and A. Ong (Oxford: Wiley-Blackwell), 1-21. doi: 10.1002/9781444346800

Ruet, J. (2007). "Muddling with water systems in Delhi: the race and interface between multilateral, state, civil and private society actors," Paper Presented at the Concluding Seminar on the Indo-European Research Programme on Urban Actors, Policies and Governance in Four Indian Metropolitan Cities (New Delhi). doi: 10.1016/j.cities.2006.10.001

Sharan, A. (2006). In the city, out of place: environment and modernity, Delhi 1860 s to 1960. Econ. Polit. Week. 41, 4905-4911. doi: 10.2307/44 18951
Sheikh, S., Sharma, S., and Banda, S. (2015). The Delhi Jal Board (DJB). New Delhi: Centre for Policy Research.

Shiva, V. (2006). Resisting Water Privatisation, Building Water Democracy. Mexico City: World Water Forum. p. 21.

Sims, K. (2021). Infrastructure violence and retroliberal development: connectivity and dispossession in Laos. Third World Quar. 42, 1788-1808. doi: 10.1080/01436597.2021.1920831

Speak, S. (2012). Planning for the needs of urban poor in the global South: the value of a feminist approach. Plann. Theory 11, 343-360. doi: $10.1177 / 1473095212440424$

Tarlo, E. (2003). Unsettling Memories: Narratives of the Emergency in Delhi. New Delhi: Permanent Black.

Tarrow, S. (2018). Mann, war, and cyber space: dualities of infrastructural power. Amer. Theory Soc. 47, 61-85. doi: 10.1007/s11186-018-9306-x

Truelove, Y. (2018). Negotiating state of power: producing illegality, bureaucratic arbitrariness, and distributive injustices in Delhi. Environ. Plann. D Soc. Space. 36, 949-967. doi: 10.1177/0263775818759967

Truelove, Y. (2019). Rethinking water insecurity, inequality and infrastructure through an embodied urban political ecology. WIREs Water 3:e1342. doi: $10.1002 /$ wat 2.1342

Truelove, Y., and Mawdsley, E. (2011). "Class and criminality: discourses of water and citizenship in clean, green Delhi," in A Companion to the Anthropology of India, ed I. Clark-Decès (Sussex: John Wiley \& Sons), 419. doi: 10.1002/9781444390599.ch22

Truelove, Y., and O’Reilly, K. (2020). Making India's cleanest city: sanitation, intersectionality, and infrastructural violence. Environ. Plann. E Nat. Space 4, 718-735. doi: 10.1177/2514848620941521

Watson, V. (2009). "The planned city sweeps the poor away...": urban planning and 21st century urbanisation. Prog. Plann. 72, 151-193. doi: 10.1016/j.progress.2009.06.002

Wescoat, J. (2014). Conserving urban water heritage in multicentered regions: an historical-geographic approach to early modern Delhi. Change Over Time 4, 142-166. doi: 10.1353/cot.201 4.0003

Conflict of Interest: The authors declare that the research was conducted in the absence of any commercial or financial relationships that could be construed as a potential conflict of interest.

Publisher's Note: All claims expressed in this article are solely those of the authors and do not necessarily represent those of their affiliated organizations, or those of the publisher, the editors and the reviewers. Any product that may be evaluated in this article, or claim that may be made by its manufacturer, is not guaranteed or endorsed by the publisher.

Copyright (c) 2021 Kumar, Singh, Cooper, Mdee and Singhal. This is an open-access article distributed under the terms of the Creative Commons Attribution License (CC BY). The use, distribution or reproduction in other forums is permitted, provided the original author(s) and the copyright owner(s) are credited and that the original publication in this journal is cited, in accordance with accepted academic practice. No use, distribution or reproduction is permitted which does not comply with these terms. 